\title{
Preserving Local Wisdoms for Village Good Governance Management in Industry 4.0 Era (Study of North Coastal Area, Central Java, Indonesia)
}

\author{
Rodiyah $^{1}$, Ridwan Arifin ${ }^{2}$, Dani Muhtada ${ }^{3}$, Indah Sri Utari ${ }^{4}$, Waspiah $^{5}$ \\ \{rodiyah@mail.unnes.ac.id ${ }^{1}$, ridwan.arifin@mail.unnes.ac.id ${ }^{2}$, dmuhtada@mail.unnes.ac.id ${ }^{3}$ \\ indahsuji@gmail.com ${ }^{4}$,waspiahtangwun@gmail.com $\left.{ }^{5}\right\}$ \\ ${ }^{1}$ Department of Administrative \& Constitutional Law Faculty of Law Universitas Negeri Semarang, \\ Indonesia, Indonesia \\ ${ }^{2}$ Criminal Law Department Faculty of Law Universitas Negeri Semarang, Indonesia \\ ${ }^{3}$ Faculty of Law Universitas Negeri Semarang, Indonesia \\ ${ }^{4}$ Faculty of Law Universitas Negeri Semarang, Indonesia \\ ${ }^{5}$ Department of Private and Commercial Law Faculty of Law Universitas Negeri Semarang, \\ Indonesia
}

\begin{abstract}
Industry 4.0 Era has impacted not only on national level, but also local level on the village. This kind of era brings big impact especially related to the existing local wisdom values. The Era pushed the changes in all aspects, including the management of village government itself. When the Era meet the local wisdom values it bring up some problems, especially between modern vis a vis traditional approach. Method: This research focus on how local wisdom values used to promote a good governance management on the villages. The study conducted on North Coastal Area, Central Java Province, Indonesia. The study used empirical legal approach with direct observation and interview. Finding: The research emphasized that, less than 50\% villages in North Coastal Area of Central Java has been optimize a local wisdom values on their village management systems, and the rest is not. Combining local wisdom to answer the challenges on Industry 4.0 Era have some challenges, one of the challenges is the capacity of government official on performing their duties on formulating laws, regulations, and policy to strengthening a good governance. Conclusion: The study was concluded that need to formulate a special method on formulating policy for village to face the Industry 4.0 Era on conducting Good Governance concept.
\end{abstract}

Keywords: good governance; local wisdom; industry 4.0 era; North Coastal Area

\section{Introduction}

After the enactment of Law Number 6 of 2014 concerning Villages (hereinafter referred to as the Village Law), various changes took place, ranging from authority to up to the flow of funds from the National Income and Expenditure Budget (ABPN) intended for villages as a form of mandate from the village law. As a result of these facts the challenges in the management process and the politics of seizing the village head position, the quality of human resources in managing village management and the quality of the BPD in the mechanism for making APBDes are increasingly complicated. Various cases of irregularities began to emerge, ranging from corruption, bribery of abuse of power, misuse of village funds, even 
maladministration of village fund management. With funds of $10 \%$ from the state budget, amounting to 59.2 trillion for 72 thousand villages in Indonesia, not to mention the $10 \%$ rule of the regional budget, it is predicted to make the village nervous and stuttering in the management of village governance and trigger potential village actors to fight for positions. villages including unhealthy positions of village officials. Rodiyah (2014) shows that the problem of village management rests on the management of deprived village management of the actual value of local wisdom if local values are used in the administration of village governance will strengthen the achievement of equitable prosperity goals in the village [35] [38].

Meanwhile, village development has been increasingly challenging and encountered challenges and obstacles, especially in the increasingly open conditions of the regional economy and more democratic political life. Lack of attention to village development, according to various studies [18] [2] [27] [3] [29] [17]. will have a direct impact on national development. Villages should be seen as an important element in the formulation of strategic development plans and policies in Indonesia. In fact, village development has a very important and strategic role in the framework of National Development and Regional Development, because in it there is an element of equitable development and its results and directly touches the interests of some people. In the development of the village, the government has a role as a subsystem of the system of governance in Indonesia, so that the village has the authority, duties and obligations to regulate and manage the interests of the community itself, or better known as Regional Autonomy [9] [13] [11] [37].

In relation to the industrial revolution era 4.0, village development has its own challenges, besides the issue of information disclosure and public access, but on the issue of human resources in facing this era and the clash of traditional values with global currents. Industrial era 4.0 for the village undeniably has an impact on the weakening of local values (local wisdom) not only in village development but also village management mechanisms based on local wisdom. Various conditions in several regions in Indonesia, such as Central Java, show that the values of local wisdom are increasingly pressed by global currents, especially in the modern era and the industrial revolution 4.0. Quickly, the community must follow the patterns in the industrial revolution 4.0 which put more emphasis on optimizing the use of technology and transparency, and industrialization of all sectors [29] [41].

Industrial revolution 4.0, as well as globalization and mobilization of access to data and information are supported by the development of machines that can learn on their own, while it becomes a challenge in the development of modern village management. The village community is currently faced with new things both in terms of work, changes in methods and tools needed for the development and progress of each village. Especially with the development of the industrial era that provides opportunities and challenges with the development of online media, e-commerce and social media. The old ways will be replaced with more global, effective, fast, and information technology-based methods. Of course these things will further ease one's work. As a matter of fact this condition did not work as expected. Many cases of abuse of power, authority, and budget in the village as a result of the rapid flow of information, as well as the inability of human resources to compensate for change. In fact, in many cases, hampered development in the village caused of the inability of the community to respond to the rapid and dynamic changes [48] [49] [7] [9] [5] [25].

In fact, in the context of village development, rural community development is development that relies on community needs by encouraging community involvement in development, the success of development can be judged by the involvement of the community in development planning. Development in the community must be applied to the system of the 
people, by the people and for the people so that the community realizes how important a development is in their area. Bureaucracy in this case the government must be able to run effectively, meaning that it can describe and carry out development in each region and here the community is the main actor of development while the government (bureaucracy) is obliged to direct, guide and create a climate that supports every development [3] [1] [26], including in terms of policy formulation village government management and poverty alleviation [28] [21].

\section{Method}

This study uses a hermeneutic approach in socio-legal qualitative research. Research with this approach will see the rule of law as the basis for policy formation by looking at the chronology of the legal process of its formation. Hermeneutically, that is, analyzing the content and context of policy material. The research will interpret the meaning of the articles in the policy so that it will get the correct meaning sociologically, philosophically and juridically [50]. The research location used is the village government in the North Coast region of Central Java. The province is very heterogeneous in terms of population dynamics, cultural heterogeneity, types of work and high economic growth. Therefore, this study is limited to five Central Coast Areas in Central Java, namely Pidodo Wetan Kendal Village, Subah Village Batang Regency, Medono Village Pekalongan City, Widuri Village Pemalang Regency, Kedungkelor Village Tegal Regency, and Suradadi Village Tegal Regency.

Data obtained by conducting interviews, observation, interpretation of documents and materials and personal experience. In accordance with the constructivism paradigm and the hermeneutic approach, the researcher takes the position as a facilitator in conducting observations using the participatory principle. In-depth interviews were conducted with openended questions but did not rule out the possibility of being conducted closed especially with informants who had a lot of information.

\section{Results and Discussion}

\subsection{Village Government Management on Post Village Law}

Law Number 6 of 2014 concerning Villages, among others, regulates the Position and Type of Villages; Village Management; Village Authority; Implementation of Village Government; Rights and Obligations of Villages and Village Communities; Village Finance and Village Assets; and Village Development and Rural Area Development.

This law mentioned, the village is domiciled in the Regency / City area, consisting of the Village and Customary Village in accordance with the mention that applies in the local area. The Government, Provincial Governments and Regency/City Governments, according to Article 7 of this Law, can arrange village arrangements, which include: a. Establishment; b. Removal; c. Incorporation; d. Status change; and e. Village Designation. The village formation referred to must meet the following requirements: a. The age limit of the parent village is at least 5 (five) years from the establishment; b. The population, namely the Java region of at least 6,000 people or 1,200 families, Bali at least 5,000 people or 1,000 families, Sumatra at least 4,000 people or 800 families, South Sulawesi and North Sulawesi at least 3,000 people or 600 families, NTB at least 2,500 people or 500 families, Central Sulawesi, 
West Sulawesi, Southeast Sulawesi, Gorontalo and South Kalimantan at least 2,000 people or 400 families, East Kalimantan, West Kalimantan, Central Kalimantan and East Kalimantan at least 1,500 people or 300 families, NTT, Maluku and North Maluku 1,000 people or 200 families, and Papua / West Papua at least 500 people or 100 families.

The village authority includes the authority in the field of village governance, implementation of village development, village community development, and empowerment of village communities based on community initiatives, original rights and village customs. Article 23 of this Law states that the Village Government shall be organized by the Village Government, which is the Village Head or referred to by another name assisted by the village apparatus or referred to by another name.

The village head is in charge of organizing village governance, village community development, and empowerment of the village community. 'In carrying out their duties, the Village Head is entitled to receive a fixed income every month, legal benefits and other receipts, as well as get health insurance, and obtain legal protection for the policies implemented', as stated on Article 26 Paragraph of Village Law (3c, d). The normative facts of Law No. 6 of 2014 mandate $10 \%$ of the state budget to be channeled to the village. So the empirical facts that follow with this logic will be a challenge in the management and political process of seizing the position of village head, the quality of human resources in the management of village administration and the quality of BPD in the mechanism for making APBDes. With funds of $10 \%$ from the state budget, amounting to 59.2 trillion for 72 thousand villages in Indonesia, not to mention the $10 \%$ rule of the regional budget, it is predicted to make the village nervous and stuttering in the management of village governance and trigger potential village actors to fight for positions, villages including unhealthy positions of village officials [6] [4] [10]. Rodiyah (2014) emphasized that the problem of village management was based on the management of deprived village management from the actual value of local wisdom if local values were used in the administration of village governance would strengthen the achievement of the goal of equitable prosperity in the village [35] [36] [37].

This fundamental change from the administration of governance in the village needs research to be able to find a model for managing village governance. Empirically, the conceptual law and reality in village government, BPD has human resources whose ability to carry out strategic functions as legislators and controlling is not optimal because they generally only educate high school. Practically the ability to carry out these strategic functions cannot be effective [40].

This condition shows that the village must be developed in accordance with the perspective of Law No. 6 of 2014. The ideal model of managing village governance to create welfare based on local wisdom values, this focus has linearity by developing the results of previous studies [36] find a model of legislative formation effective invitations namely Integrative RegMap and Regulatory Impact Assessment (IRR) which were tested with various research studies applying the IRR model [34]. This study examines, finding an ideal model of managing village governance in perspective Law No. 6 of 2014.

Empirical facts from the results of the study on 15 May 2016 showed that the Head of the Indonesian Inspectorate had examined the financial statements of 40 villages as a sampling, and most of the audited financial statements were found to have problems, particularly administrative problems. Among other things, the late submission of village fund reports and a number of other administrative issues. BPKP is currently developing the Village Financial Administration System to expedite the budget reporting process. The findings of corruption report have not been found in the report, only limited to administrative problems. Checking or reviewing village funds is done once a year. The periodic review was carried out following a 
surging budget for villages since the Village Law No.6 of 2014 was enacted. The new regulation not only encourages greater funds to go to the village, but also transfers some authority to the village. The position of the village has become more autonomous than before.

\subsection{Good Governance for Village Management by Promoting Local Wisdoms Approach (Case on North Coastal Area of Central Java)}

Good governance, one of which is in the form of supervision, according to Terry in Torang [45] supervision as part of control will record organizational development towards the expected goals and allow leaders to detect deviations from planning in time to take corrective action before it's too late with determine and determine what must be done and expected. Supervision in the implementation of the internal development of the organization is carried out by the Village Consultative Body (Badan Permusyawatan Desa, BPD) and the Community Empowerment Institute (LPM), both institutions that oversee every implementation of development carried out by the village government of Kedungkelor, Pidodo Weta, Subah, Widuri, Medono, and Suradadi. Externally carried out by the community itself who can oversee the implementation of development carried out by the village government, this as stated by the Secretary of one of the villages (Kedungkelor Village) stated that:

The village head always gives direction to all government apparatuses so that the implementation of development will be effective because many villages currently supervise, so the leadership always gives direction so that the program runs effectively. Well, that often becomes an obstacle in the process of implementing village development when all development programs in each village go down, we scramble to get materials for development because of the decline in development programs in the same district, while in the village the main focus is physical development (Adi Warnoto, personal interview, May 20, 2019).

The role of the village government in implementing Good Governance is the implementation of the duties, functions, authorities, rights, and obligations of the village government in planning, implementing development in the village, specifically relating to village governance. In the context of building good governance, in the current reform era, good governance has become something that cannot be negotiated and its existence must be fulfilled. The principles of good governance include, among others: (1) accountability which is defined as an obligation to account for its performance; (2) openness and transparency in the sense that the community can not only access a policy but also plays a role in the formulation process; (4) community participation in various general government and development activities [47].

In general, good governance is with a clean government. Here is an initial thought, about good governance as a new paradigm of development administration / management. Good Governance is a form of development management, which is also called development administration [8] [12]. Development Administration/Development Management places the role of central government. The government becomes the agent of change of a developing society in a developing country. In Good Governance, it is no longer the government, but also citizens, the public and especially the business/private sector that plays a role in governance. So there are government organizers, private organizers, even by community organizations (NGOs for example). This is also due to changes in the development paradigm by reviewing the role of government in development, which initially acted as regulators and market 
participants. Being how to create a conductive climate and invest in infrastructure that supports the business world.

Good governance itself has several definitions that have been put forward by several institutions. One of them is the United Nations Development Program (UNDP defining good governance as a responsibility of economic authority, administrative authority, and political authority to regulate the country's social problems. From this understanding, it can be seen that three main sectors of government authority are then used for the greatest interests of the people. Meanwhile, the World Bank looks at governance in economic terms. In its definition, it is said that a country has achieved good governance if it has succeeded in implementing a strong, responsible and responsible state development regulation system while still being in line with democratic principles and efficient market principles. In addition, good governance will avoid mistakes in the allocation of development funds, including early prevention of corruption. Good governance will also run the budget in a disciplined manner so that people's business activities can grow well [14] [15].

At the very least, in general there are four indicators of good governance, including the implementation of good village governance, namely: (1) transparency; (2) participation; (3) accountability; and (4) coordination [16] [19] [20]. Transparency is an open process to convey information or activities carried out. The hope is that external parties who are indirectly responsible can participate in providing supervision. Facilitating access to information is an important factor in creating transparency.

In its development, transparency metamorphosed into a more modern and all-digital form. This can be seen from the many forms of cyber portals, such as e-government management, which greatly enables the public to monitor and see directly the administration of government [22] [23] [24). In five villages on the North Coast of Central Java, this transparency process was combined with the values of local wisdom, where technological advances were used as media for information and community hearing, as well as introducing the culture and potential of village communities. In Kedungkelor Village, for instance, the use of social media in informing various activities in the Village is one form of protecting local values in the era of the industrial revolution 4.0 in village management.

Furthermore, participation refers to the involvement of all stakeholders in planning policies. Input from various parties in the policy making process can help policymakers consider various issues, perspectives, and alternative options in solving a problem [30] [32] [31]. The participation process opens up opportunities for policy makers to gain new knowledge, integrate public expectations into the policy making process, as well as anticipate social conflicts that may arise. Components that guarantee access to participation include, the availability of formal space through relevant forums, the existence of mechanisms to ensure public participation, an inclusive and open process, and the existence of certainty of input from the public will be accommodated in policy making.

The form of village community participation in the formulation of various village policies can be seen from the high interest of the community in various meetings that were held. In the five villages, at least, each village meeting was attended by $70 \%$ of the villagers invited to the meeting. Even more than $50 \%$ actively provide input. This participation is also related to preserving the values of the local wisdom of the village community. For example, various village regulations regarding the preservation of village culture, clothing, food, and other forms of activity.

Meanwhile, accountability itself is defined as a form of accountability for the rules that have been made. This process also tests how credible a policy is not in favor of certain groups. Accountability will pass certain testing processes [33] [39]. This structured process is 
expected to be able to read the gaps in error, such as budget irregularities or inadequate devolution of power. The accountability mechanism also provides an opportunity for policy makers to ask for clarification and accountability if there are things that are not in accordance with the consensus in implementing governance in certain fields [44].

Last but not least, coordination in village management, where coordination is considered as a mechanism that ensures that all stakeholders who have a common interest have the same views. This common view can be realized by integrating the vision and mission in each institution. Coordination becomes a very important factor, because coordination chaos can cause work efficiency and effectiveness to be disrupted [42] [43] [46].

\section{Conclusions}

The Industrial Revolution Era 4.0 greatly impacted the patterns of government management, including the village administration. Due to the rapid information in this era, so we need a special attention in maintaining the values of local wisdom and governance. The concerns about currents global that are rapidly changing the mindset of villagers, including in determining village policies resulting in various obstacles, one of which is hampered development in the village. Strengthening the values of local wisdom in good village management, including the formulation of village policies, becomes very important after the Village Law is implemented. Not only in the issue of village financial management, but also the bureaucracy and empowerment of rural communities in the industrial era 4.0 based on local wisdom. However, it is necessary to find more effective steps in village management towards good village governance in the industrial revolution 4.0 era with a local wisdom approach.

\section{Acknowledgments}

This research was funded through the 2019 National Strategic Applied Research (multiyear) scheme, Universitas Negeri Semarang and Ministry of Research, Technology and Higher Education Republic of Indonesia. Our gratitude goes to the Village Head and all the villagers in five villages: namely Pidodo Wetan Kendal Village, Subah Batang Regency, Medono Village Pekalongan City, Widuri Village Pemalang Regency, Kedungkelor Village Tegal Regency, and Suradadi Village Tegal Regency.

\section{References}

[1] Antlöv, H., Wetterberg, A., \& Dharmawan, L.: Village governance, community life, and the 2014 village law in Indonesia. Bulletin of Indonesian Economic Studies. Vol. 52 No. 2, pp 161-183 (2016).

[2] Arifin, R.: Democracy on Indonesian Legal Reform: How Can People Participate on Laws and Regulations Establishment Process'. JILS (Journal of Indonesian Legal Studies). Vol. 2 No. 2, pp. 155-158 (2017). 
[3] Ash-shidiqqi, E. A., \& Wibisono, H.: Corruption and Village: Accountability of Village Fund Management on Preventing Corruption (Problems and Challenges). JILS (Journal of Indonesian Legal Studies). Vol. 3 No. 2, pp. 195-212. (2018).

[4] Atmadja, A. T., Saputra, K. A. K., \& Koswara, M. K.: The Influence of Village Conflict, Village Apparatus Ability, Village Facilitator Competency and Commitment of Local Government on The Success of Budget Management. Academy of Accounting and Financial Studies Journal. Vol. 22 No. 1, pp. 1-11 (2018)..

[5] Atmadja, A. T., \& Saputra, A. K.: Pencegahan Fraud dalam Pengelolaan Keuangan Desa. Jurnal Ilmiah Akuntansi dan Bisnis. Vol. 12 No. 1, pp. 7-16 (2017).

[6] Aziz, N. L. L.: Otonomi Desa dan Efektivitas Dana Desa. Jurnal Penelitian Politik. Vol. 13 No. 2, pp. 193-211 (2016).

[7] Bowen, J. R.: On the political construction of tradition: Gotong Royong in Indonesia. The Journal of Asian Studies. Vol. 45 No. 3, pp. 545-561 (1986).

[8] Brinkerhoff, D. W.: Accountability and Good Governance: Concepts and Issues. In International Development Governance, pp. 269-287. Routledge, UK (2017).

[9] Dalimunthe, D. M. J. F., \& Fadli, I. M.: A study on the impact of government complexity and regional government's size on human development index in North Sumatera, Indonesia. European Journal of Accounting Auditing and Finance Research. Vol. 3 No.1, pp. 1-19 (2015).

[10] Darmi, T.: Optimalisasi Peran Perempuan Berbasis Modal Sosial pada Sektor Pemerintahan Desa (Studi pada Pengelolaan Dana Desa). Jurnal Antropologi: Isu-Isu Sosial Budaya. Vol.18 No. 1,pp. 21-27 (2016).

[11] Dilaga, A.P.: Politics of Law on Protection to Folklore in a Regional Autonomy Perspective: Rights for Indigenous People. JILS (Journal of Indonesian Legal Studies). Vol. 2 No.1, pp. 25-46 (2017).

[12] De Graaf, G., \& Paanakker, H.: Good Governance: Performance Values and Procedural Values in Conflict. The American Review of Public Administration. Vol. 45 No. 6, pp. 635-652 (2015)..

[13] Ekosafitri, K. H., Rustiadi, E., \& Yulianda, F.: Pengembangan Wilayah Pesisir Pantai Utara Jawa Tengah Berdasarkan Infrastruktur Daerah: Studi Kasus Kabupaten Jepara. Journal of Regional and Rural Development Planning. Vol. 1 No. 2, pp. 145-157 (2017).

[14] Fatmasari, D.: Analisis Sosial Ekonomi dan Budaya Masyarakat Pesisir Desa Waruduwur, Kecamatan Mundu, Kabupaten Cirebon. Al-Amwal: Jurnal Ekonomi dan Perbankan Syari'ah. Vol. 6 No.1, pp. 144-166 (2014).

[15] Fahri, L. N.: Pengaruh Pelaksanaan Kebijakan Dana Desa terhadap Manajemen Keuangan Desa dalam Meningkatkan Efektivitas Program Pembangunan Desa. Jurnal Publik: Jurnal Ilmiah Bidang Ilmu Administrasi Negara. Vol. 11 No.1, pp. 75-88 (2017).

[16] Hendriks, F.: Understanding Good Urban Governance: Essentials, Shifts, and Values. Urban Affairs Review. Vol. 50 No. 4, pp. 553-576 (2014).

[17] Helliwell, J. F., Huang, H., Grover, S., \& Wang, S.: Empirical Linkages between Good Governance and National Well-Being. Journal of Comparative Economics. Vol. 46 No. 4, pp. 1332-1346 (2018)..

[18] Hernowo, B.: Kajian Pembangunan Ekonomi Desa untuk Mengatasi Kemiskinan. Jurnal Info Kajian Bappenas. Vol. 1 No.1, pp. 5-18 (2004).

[19] Holzhacker, R. L., Wittek, R., \& Woltjer, J.: Decentralization and Governance for Sustainable Society in Indonesia. In Decentralization and Governance in Indonesia, pp. 3-29. Springer, Cham (2016). 
[20] Irawan, N.: Tata Kelola Pemerintahan Desa Era UU Desa, pp. 20-45. Yayasan Pustaka Obor Indonesia, Jakarta (2017).

[21] Jhody, P.S.: Poverty Reduction in Perspective of Public Service Reform: A Study on Legal and Social Analysis (Case of Sragen, Indonesia). JILS (Journal of Indonesian Legal Studies). Vol. 2 No. 2, pp. 131-144 (2017).

[22] Karyanto, R.: Apakah Penyaluran Dana Desa Terhambat oleh Karakteristik Kepala Desa? Jurnal Akuntansi dan Bisnis. Vol. 16 No.2, pp. 149-161 (2016).

[23] Khoiriah, S., \& Meylina, U.: Analisis Sistem Pengelolaan Dana Desa Berdasarkan Regulasi Keuangan Desa. Masalah-Masalah Hukum. Vol. 46 No.1, pp. $20-29$ (2017).

[24] Kumalasari, D., \& Riharjo, I. B.: Transparansi dan Akuntabilitas Pemerintah Desa dalam Pengelolaan Alokasi Dana Desa. Jurnal ilmu dan riset akuntansi. Vol. 5 No.11, pp. 1-15 (2016).

[25] Kurniawan, J. A.: Contested Land, Contesting Laws. A Context of Legal Pluralism and Industrialization in Indonesia'. Sortuz: Oñati Journal of Emergent Socio-Legal Studies. Vol. 6 No. 2, pp. 93-106 (2015).

[26] Lewis, B. D.: Decentralising to villages in Indonesia: Money (and other) mistakes. Public Administration and Development. Vol. 35 No. 5, pp. 347-359 (2015).

[27] Maharani, A.M.: BPD Empowerment Program in Optimizing Village Financial Implementation (Perspective Law No. 6 of 2014). JILS (Journal of Indonesian Legal Studies). Vol. 3 No. 1, pp. 93-108 (2018).

[28] Miranti, R., Duncan, A., \& Cassells, R.: Revisiting the impact of consumption growth and inequality on poverty in Indonesia during decentralisation. Bulletin of Indonesian Economic Studies. Vol. 50 No. 3, pp. 461-482 (2014).

[29] Muhtada, D.: The Prospects for Public Management Reform in Indonesia. JILS (Journal of Indonesian Legal Studies). Vol. 2 No. 2, pp. 145-154 (2017).

[30] Mungiu-Pippidi, A.: The Quest for Good Governance: How Societies Develop Control of Corruption, pp. 157-160. Cambridge University Press, UK (2015).

[31] Mungiu-Pippidi, A.: The Quest for Good Governance: Learning from Virtuous Circle's. Journal of Democracy. Vol. 27 No.1, pp. 95-109 (2016).

[32] Nafidah, L. N., \& Suryaningtyas, M.: Akuntabilitas Pengelolaan Alokasi Dana Desa Dalam Upaya Meningkatkan Pembangunan Dan Pemberdayaan Masyarakat. BISNIS: Jurnal Bisnis dan Manajemen Islam. Vol. 3 No.1, pp. 214-239 (2016).

[33] Nugrahaningsih, P., Falikhatun, F., \& Winarna, J.: Optimalisasi Dana Desa dengan Pengembangan Badan Usaha Milik Desa (BUM Des) Menuju Desa Mandiri. Jurnal Akuntansi dan Bisnis. Vol. 16 No.1, pp. 37-45 (2016).

[34] Purnamasari, H. \& Ramdani, R.: Manajemen Pemerintahan dalam Pembangunan Desa di Desa Lemahabang Kecamatan Lemahabang Kabupaten Karawang. Jurnal Politikom Indonesiana. Vol. 3 No.1, pp. 1-13 (2018).

[35] Rodiyah, R.: The Accelerated Model of The Right To Work Through The Harmonization of Manpower Policies (A Case Study of Outsourcing Manpower after the Constitutional Court Decision Number 27/PUU-IX/2011 about the Review of Law Number 13 of 2003 Concerning Substantive Justice Attainment)'. South East Asia Journal of Contemporary Business, Economics and Law. Vol. 4 No. 3, pp. 65-71 (2014).

[36] Rodiyah, R.: Reformation of the Administration of Village Government in Indonesia Based on Law Number 6 of 2014 on Villages (Comparing Normative and Empirical Facts on Villagers Participation)', Advances in Social Science, Education and Humanities Research, Proceedings of the 1st International Conference on Indonesian Legal Studies (ICILS 2018), Vol. 192, pp. 264-269 (2018). 
[37] Rodiyah, R., Utari, I.S., Muhtada, D.: Village Bureaucracy Reform in Democratic and Autonomy Era In Indonesia: Study of The Establishment of Laws and Regulations Method By IRR Model. South East Asia Journal of Contemporary Business, Economics and Law. Vol. 17 No. 4, pp. 1-6 (2018).

[38] Rodiyah, R. \& Waspiah, W.: Acceleration of Acquisition of Copyright Through VillageOwned Enterprises (BUMDES) In Indonesia (Study in Kedungkelor Village, Warureja, Tegal Regency, Central Java)'. South East Asia Journal of Contemporary Business, Economics and Law. Vol. 18 No. 4, pp. 55-65 (2019).

[39] Rotberg, R. I.: Good Governance Means Performance and Results. Governance. Vol. 27 No.3, pp. 511-518 (2014).

[40] Roza, D.: Peran Badan Permusyawaratan Desa di Dalam Pembangunan Desa dan Pengawasan Keuangan Desa. Padjadjaran Journal of Law. Vol. 4 No.3, pp. 606-624 (2017).

[41] Sudarwanto, B. et al.: The Uniqueness and Complexity of Kampung City Bustaman Semarang Indonesia' IOP Conf. Ser.: Earth Environ. Sci. 99, pp. 1-7, (2017). DOI: 10.1088/1755-1315/99/1/012005.

[42] Sugiharto, D. Y. P., \& Kusumandari, R. B.: Model Development in the Context of Vocational Village Community Empowerment in Central Java. International Journal of Information and Education Technology. Vol. 6 No. 7, p. 564 (2016).

[43] Susan, N., \& Budirahayu, T.: Village Government Capacity in the Implementation of Village Law No. 6 of 2015 in Indonesia. In Sustainable Future for Human Security, pp. 17-27. Springer, Singapore (2018).

[44] Temenggung, Y. A.: Rural Financial Management In Perspective Law No. 6 Of 2014 Concerning The Village. International Journal of Social Sciences,. Vol. 43 No.1, pp. 42 54 (2016).

[45] Torang, S.: Organisasi dan Manajemen (Perilaku, Struktur, Budaya \& Perubahan Organisasi, pp.32-4. Alfabeta, Bandung (2013).

[46] Ulum, M.B, \& Wildana, D.T.: Promoting the Right to Education through A Card: A Paradox of Indonesia's Educational Policy?. JILS (Journal of Indonesian Legal Studies). Vol. 4 No.1, pp. 143-160 (2019). https://doi.org/10.15294/jils.v4i01.26973

[47] Warren, C., \& Visser, L.: The Local Turn: an Introductory Essay Revisiting Leadership, Elite Capture and Good Governance in Indonesian Conservation and Development Programs. Human Ecology. Vol. 44 No.3, pp. 277-286 (2016).

[48] Widodo, I.: Dana Desa dan Demokrasi dalam Perspektif Desentralisasi Fiskal. Politik Indonesia: Indonesian Political Science Review. Vol. 2 No.1, pp. 65-85 (2017).

[49] Wismadi, A., Brussel, M., Zuidgeest, M., Sutomo, H., Nugroho, L. E., \& van Maarseveen, M.: Effect of Neighbouring Village Conditions and Infrastructure Interdependency on Economic Opportunity: A Case Study of The Yogyakarta Region, Indonesia. Computers, Environment and Urban Systems. Vol. 36 No.5, pp. 371-385 (2012).

[50] Wignjosoebroto, S.: Hukum: Paradigma, Metode dan Dinamika Masalahnya, pp. 15-24. ELSAM-HUMA, Jakarta (2002). 